\title{
Nutritional Composition of Sea Cucumber Isostichopus sp.
}

\author{
Wensy Vergara*, Adriana Rodríguez \\ Grupo de Investigación y Desarrollo Tecnológico en Acuicultura, Facultad de Ingenierías, Universidad del \\ Magdalena, Santa Marta, Colombia \\ Email: "ingpesqueraunimagdalena@gmail.com
}

Received 16 January 2016; accepted 18 March 2016; published 21 March 2016

Copyright (C) 2016 by authors and Scientific Research Publishing Inc.

This work is licensed under the Creative Commons Attribution International License (CC BY).

http://creativecommons.org/licenses/by/4.0/

(c) ()

\section{Abstract}

The knowledge of the chemical composition of invertebrates as sea cucumber contributes to improving our understanding of these living organisms. This study compared the chemical composition of wild sea cucumber Isostichopus sp., between February 2013 and January 2014. Sea cucumbers were captured by hand by artisanal fishermen and transported alive to the laboratory of Aquaculture of the Universidad del Magdalena (Colombia), where they were subsequently killed and taken to freeze until analysis. For proximate analysis $20 \mathrm{~g}$ of muscle were used for each sample. The analysis (in triplicate) was performed according to [1]. Significant differences $(p<0.05)$ in the protein content, lipids and ash were found. The chemical composition ranged from $2.74 \%$ to $6.63 \%$ for protein; about $0.07 \%$ to $0.35 \%$ for lipids; $3.16 \%$ to $3.81 \%$ for ash; between $83.74 \%$ and $\mathbf{8 6 . 9 2 \%}$ for moisture. Chemical composition of muscle Isostichopus sp. was similar to that reported for fresh sea cucumbers internationally traded, which indicates that it is a species with a competitive commercial value for use in food.

\section{Keywords}

Caribbean Sea, Chemical Composition, Isostichopus, Protein, Lipids

\section{Introduction}

Water, inorganic matter and a variety of organic compounds are part of the chemical composition of aquatic organisms [2]-[5]. This composition might be influenced by many factors such as physiological characteristics, habitat and life cycle of organisms, or by the environmental characteristics in where they live [5]-[7].

Proteins, lipids and minerals are the main constituents of living organisms and knowledge about their concen-

${ }^{*}$ Corresponding author.

How to cite this paper: Vergara, W. and Rodríguez, A. (2016) Nutritional Composition of Sea Cucumber Isostichopus sp. Natural Resources, 7, 130-137. http://dx.doi.org/10.4236/nr.2016.73013 
tration provides information related to the physiological and nutritional value of organisms [4] [5].

In living organisms, proteins play an important role in most biological processes, such as transportation, storage, immune protection and the generation and transmission of nerve impulses [5] [8]. Lipids are hydrophobic substances that serve as energy reserves, contribute to the waterline and are structural components of cell membranes and organelles [9]. Minerals are involved in various biological functions with great importance as the formation of skeletal structures in the osmotic processes and muscle contraction [10].

At present there is little information on the chemical composition in many aquatic species. Chemical composition studies comprise mainly organisms with economic importance such as freshwater fish and marine fish, crustaceans and mollusks, leaving away organism like sea cucumbers [11]-[16]. Thus, the information about nutritional composition is subject currently only to organisms of economic importance.

Isostichopus is within genres that are commercially exploited. Their high value is due to its use as food and in traditional Asian medicine. Studies in sea cucumbers include gender distribution, taxonomy, biological activity, aquaculture and nutritional composition besides others [17]-[19]. Analysis on fresh proximal composition has shown that these marine invertebrates have a high nutritional value, which can vary depending on the species, feeding behavior and seasonal variations [20]-[23].

From a nutritional standpoint, sea cucumbers are of great value because of its high protein content, its low fat percentage and vitamin content, among which highlights the vitamins $\mathrm{A}, \mathrm{B}_{1}$ (thiamine), $\mathrm{B}_{2}$ (riboflavin ), $\mathrm{B}_{3}$ (niacin) and minerals, especially calcium, magnesium, iron and zinc [24] [25].

In Colombia, there are few studies on sea cucumbers [26]-[31]. This group of invertebrates is not well known and only some artisanal fishermen occasionally consume them as food. Although Isostichopus is a genus with high ecological impact due to the fact that they remove and oxygenate the natural substrate in which they live, and it's a genus with great commercial interest worldwide, and not yet known aspects related to its proximal composition. Therefore, the objective of this research was to study the proximate composition of fresh Isostichopus sp., from the natural environment. The information will be useful to have basic knowledge about the nutritional values (percentages of protein, lipid, ash and moisture in the muscle) and their variations over an annual period of native species of sea cucumber in the Colombian Caribbean.

\section{Material \& Methods}

A total of sixty specimens of Isostichopus sp. were collected monthly for one year (February 2013 to January

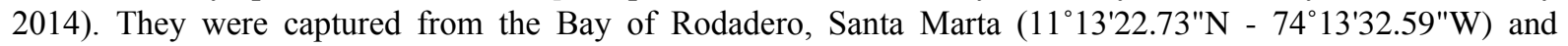
transported alive in plastic containers filled with sea water at $28^{\circ} \mathrm{C}$ and 37 Practical Salinity Units (UPS) to the Aquaculture laboratory at the University of Magdalena. Once there, they were killed by hypothermia, internal fluids were drained and body weight (232.39 $\pm 78.71 \mathrm{~g})$ was recorded with a precision scale (Brand Ohauss). Animals were cut longitudinally from the ventral portion, whereupon the viscera and the muscle bands were extracted from the body wall.

\subsection{Proximal Composition Analysis}

To chemical analysis composition $20 \mathrm{~g}$ of fresh muscle were used. The samples were processed at the Laboratory of Food Science (Universidad del Magdalena). Determining analysis (in triplicate) was performed according to [1]. The content of crude protein $(\mathrm{N} \times 6.25)$ was determined by the Kjeldahl method [1]. In the process a digester system with neutralizing gases, integrated recirculation pump and distiller (UDK 132, Velp Scrubber ${ }^{\circledR}$ SMS, Italy), titration with hydrochloric acid a digital burette $(50 \mathrm{ml})$ was used (Brand was used ${ }^{\circledR}$, Germany). Total lipids were extracted with diethyl ether extraction in a Fosstech analyzer after HCl hydrolysis and evaluated gravimetrically in an analytical balance (Adventurer-OHAUSTM, China) [1]. The inorganic content (ash weight) was obtained by incinerating the samples in a muffle furnace at $550^{\circ} \mathrm{C}$ (Vulcan $3-550^{\mathrm{TM}}$, USA). Pure dry ashes were calculated from the difference between the dry weight and wet weight. Moisture were determined using a moisture extractor digital balance (Ohaus MB45

In Colombia, two climate period are identified: a rainy season, from April to October, when fresh and brackish waters from the Magdalena River and Ciénaga Grande de Santa Marta mangrove-estuarine system, reach the shelf in the central region and a dry season, from November to March, in which Northeastern Trades Winds induce upwelling. For the Caribbean coast the maximum annual precipitation values do not exceed $2500 \mathrm{~mm}$. The average temperature is below $27^{\circ} \mathrm{C}[32]-[36]$. 


\subsection{Statistical Analysis}

To know the effect of time (a period of twelve months) on the proximal composition of Isostichopus sp., a one way analysis of variance was applied, after verification of compliance with the assumptions of normality (Kolmogorov-Smirnov) and homoscedasticity (Levene's test). Since the ANOVA yielded a significant result ( $\mathrm{p}<$ 0.05 ), the Multiple Tukey test, was also applied to determine statistically difference between months. For all these tests the statistical program Statgraphics Centurion vs. XVI (2010) was used.

\section{Results}

The chemical composition of Isostichopus sp. is presented in Table 1. The protein content varied significantly ( $\mathrm{p}<0.05$ ), and their values were in the range of $2.74 \%$ and $6.63 \%$, with the highest percentage found in July, while that minors were recorded between February and May (2013) and between November (2013) to January (2014).

Significant variations in lipids and ash between the months sampled $(\mathrm{p}<0.05)$ (Table 1$)$ were found. The lipid content ranged from $0.07 \% \pm 0.10 \%$ to $0.35 \% \pm 0.44 \%$; lipid percentages presented a variation from February to May and from June to December, being May when the highest percentage of lipid was observed. On the other hand, the ash content showed variations between the sampled months in this way, the highest percentage (3.81\% $\pm 0.11 \%)$ was observed in August, and the lowest percentage (3.16\% $\pm 0.55 \%)$, was presented in April.

The moisture content presented fluctuations during the sampled months, however it was in July where it reached its maximum value $(86.92 \% \pm 1.54 \%)$, while in January the minimum percentage of water was detected $(83.74 \% \pm 1.07 \%)$. Nevertheless, the statistical analysis showed that significant differences did not exist between the months sampled $(\mathrm{p}<0.05)$.

\section{Discussion}

Knowledge of the chemical composition of species with potential for food human consumption is of great importance for nutritional characterization, however this content, may be influenced by animals feeding, physiological characteristics, life cycle and habitat of the species, besides the environmental features [5] [37].

There are few studies related to proximal muscle composition of sea cucumbers worldwide. The results found in muscle composition of individuals of Isostichopus sp. are within the ranges reported for other species such as Stichopus japonicus, Apostichopus japonicus, Parastichopus californicus, Holothuria tremula, Holothuria scabra and Cucumaria frondosa [21] [38]-[41].

In this study the protein content for Isostichopus sp. was between $2.74 \%$ and $6.63 \%$, being within the ranges

Table 1. Chemical composition of muscle of sea cucumber Isostichopus sp., in terms of percentage (g/100g) of crude protein, lipid, ash and moisture during the months of sampling and represent the mean of tree replicates \pm Standard Deviation (Fresh samples, $\mathrm{n}=60$ ).

\begin{tabular}{|c|c|c|c|c|}
\hline Month & $\%$ Protein & \% Lipid & $\%$ Ash & \% Moisture \\
\hline Feb-13 & $3.12 \pm 0.72^{\mathrm{ab}}$ & $0.09 \pm 0.05^{\mathrm{ab}}$ & $3.77 \pm 0.35^{\mathrm{bc}}$ & $84.83 \pm 1.20^{\mathrm{a}}$ \\
\hline Mar-13 & $2.96 \pm 0.81^{\mathrm{ab}}$ & $0.13 \pm 0.15^{\mathrm{ab}}$ & $3.37 \pm 0.12^{\mathrm{ab}}$ & $85.78 \pm 2.02^{\mathrm{a}}$ \\
\hline Apr-13 & $2.74 \pm 0.79^{\mathrm{a}}$ & $0.07 \pm 0.10^{\mathrm{a}}$ & $3.16 \pm 0.55^{\mathrm{a}}$ & $86.56 \pm 2.45^{\mathrm{a}}$ \\
\hline May-13 & $3.21 \pm 0.67^{\mathrm{ab}}$ & $0.35 \pm 0.44^{\mathrm{bc}}$ & $3.36 \pm 0.16^{\mathrm{ab}}$ & $84.10 \pm 2.10^{\mathrm{a}}$ \\
\hline Jun-13 & $6.17 \pm 1.30^{\mathrm{d}}$ & $0.08 \pm 0.06^{\mathrm{a}}$ & $3.44 \pm 0.34^{\mathrm{abc}}$ & $85.66 \pm 1.64^{\mathrm{a}}$ \\
\hline Jul-13 & $6.63 \pm 0.59^{\mathrm{d}}$ & $0.16 \pm 0.07^{\mathrm{ab}}$ & $3.26 \pm 0.59^{\mathrm{a}}$ & $86.92 \pm 1.54^{\mathrm{a}}$ \\
\hline Aug-13 & $5.43 \pm 0.77^{\mathrm{c}}$ & $0.24 \pm 0.35^{\mathrm{ab}}$ & $3.81 \pm 0.11^{\mathrm{c}}$ & $83.96 \pm 1.52^{\mathrm{a}}$ \\
\hline Sep-13 & $5.34 \pm 0.71^{\mathrm{c}}$ & $0.10 \pm 0.06^{\mathrm{ab}}$ & $3.45 \pm 0.20^{\mathrm{abc}}$ & $85.11 \pm 1.85^{\mathrm{a}}$ \\
\hline Oct-13 & $4.64 \pm 0.46^{\mathrm{c}}$ & $0.13 \pm 0.09^{\mathrm{ab}}$ & $3.51 \pm 0.13^{\mathrm{abc}}$ & $84.44 \pm 1.34^{\mathrm{a}}$ \\
\hline Nov-13 & $3.70 \pm 0.93^{\mathrm{b}}$ & $0.14 \pm 0.07^{\mathrm{ab}}$ & $3.57 \pm 0.67^{\mathrm{abc}}$ & $86.44 \pm 1.37^{\mathrm{a}}$ \\
\hline Dec-13 & $3.34 \pm 0.81^{\mathrm{ab}}$ & $0.07 \pm 0.06^{\mathrm{a}}$ & $3.57 \pm 0.13^{\mathrm{abc}}$ & $86.28 \pm 2.01^{\mathrm{a}}$ \\
\hline Jan-14 & $3.15 \pm 0.78^{\mathrm{ab}}$ & $0.07 \pm 0.05^{\mathrm{a}}$ & $3.22 \pm 0.26^{\mathrm{a}}$ & $83.74 \pm 1.07^{\mathrm{a}}$ \\
\hline
\end{tabular}

* abcd Values in the same column with the different superscripts are significantly different $(\mathrm{p}<0.05)$. 
reported by [42] in Stichopus japonicus (3.31\% and 6.78\%) and [21], to Parastichopus spp. (2.5\% and 13.8\%); in turn, they are in the average range reported by [43] for Apostichopus japonicus (1.13\% and 3.99\%), although in this case the inferior value of this is very lower compared to that found in the species in this study. Moreover, Isostichopus sp. records are below those obtained by [24], for Thelenota pineapple (16.64\%) and Acaudina molpadioides (12.94\%), or are relatively lower when compared to those reported by [23], in H. polii, H. tubulosa and H. mammata (7.88 and 8.829\%).

According to [20]-[23]), seasonal variations affect bromatological content of sea cucumbers. Throughout this study, the percentage of protein presented dramatically fluctuations with the highest values from June to October at its maximum increase in July. This case is contrary to what was reported by [42] who reported that Stichopus japonicus showed variations in the protein content from January to August, while [40] reported values of protein of $9.53 \%$ and $5.78 \%$ of $H$. scabra in the spring and summer, indicating that these fluctuations may be related to the physiological characteristics, seasonal variations, the life cycle of the species and the and the study region [5].

Moreover, the period where the highest values of protein were found coincides with the breeding season of the species recorded by [30]. It is possible that increased protein content has an influence on the mobilization of nutrients during the breeding season and subsequent release of sea cucumbers. It is well known that good nutrition on organisms in general is critical to optimizing reproductive processes and normal development of embryos. An optimal level of nutrients will determine the success in the morphology of eggs and hatching rates. However studies related to nutritional composition, diet, breeding seasons and reproductive success in sea cucumbers, are scarce, so this would be a preliminary reference on what happens inside the native sea cucumbers of the region against the reproductive processes vs. the composition and nutritional requirements thereof. Then, deep future studies should address in this regard.

Moreover, total lipid content found in this study presented variations during all the sampled months: the lowest percentage was observed in April and the largest increase in May. Despite belonging to the same family, the fat content of Isostichopus sp. (0.07 than $0.35 \%$,) was much lower than that reported by Tanikawa et al. [42], for Stichopus japonicus (0.56\% to $2.3 \%$ ), by [44] to Apostichopus japonicus ( $0.28 \%$ to $0.33 \%)$ and the findings by [38], to Parastichopus californicus (0.57\% and 0.44\%). While [24], reported values below related in this study, with a percentage of $0.27 \%$ to $0.03 \%$ for Thelenota ananas and Acaudina molpadioides. Finally, the results recorded for Isostichopus sp. in this work contrast with those found by [23] to H. tubulosa, H. polii and H. mammata who report lipid content between $0.09 \%, 0.15 \%$ and $0.18 \%$ respectively.

According to what observed by [45], "lipids are greater metabolic energy source in reproduction processes of fish, which can be mobilized from a tissue storage until oocytes developing food purchased directly or synthesized de novo in the ovarian follicle”. In sea cucumbers is little the knowledge in this regard. According [42] variations in the fat content may be related to gonadal growth. This study showed an increase in lipid values in May, when as [30], found Isostichopus sp. show gonads in vitellogenic stage and previtellogenic oocytes stage. Thus, the lipid concentration is likely to affect the reproductive potential of the species, which previously mobilize its lipid reserves for reproduction and development of gamete. As mentioned by [46] and [47], who report that holothurians may have wide variations in lipid concentrations (and polyunsaturated fatty acids), depending on the reproductive pattern and the type of development of each specie, biochemical composition being listed as a factor species specific. Future studies should address in this regard, in order to know the class of lipid and the role they have on the reproductive function of the species.

Many factors are linked with changes in chemical composition in living organism [16]. Environmental changes has been reported as one of a key factor which could influences proximal composition in marine invertebrates [16] [48]-[50]. Furthermore sea cucumber physiology, seasonal variations in feeding behavior, feeding regimes and food supply from sea environment are factors which may help explained variations on nutritional or chemical composition [23] [51]-[53]. In addition, as state [54], sea cucumbers may have different chemical composition including those sampled from the same environmental conditions. In Colombia there are two climatic periods: dry season and rainy season [36]. In this sense, lower protein and lipid levels were found during the dry season and the highest percentages were registered in rainy season which is also consistent with lower water temperature $\left(27^{\circ} \mathrm{C}\right)$ in the dry season and with a higher water temperature $\left(28^{\circ} \mathrm{C}\right)$ in the rainy season. Authors as [55] argue that changes in the lipid content in the sea cucumber are linked to the season and habitat. Similar trends have been found by [56] and [50].

Ash content ranged from $3.16 \%$ to $3.81 \%$; these variations are above the values reported by [42] for S. japo- 
nicus and [24] to T. ananas and A. molpadioides. Native values of sea cucumbers are lower than those reported by Aydin et al. [23], for H. polii, H. tubulosa and H. mammata with a range between 5.13\% and 7.85\%. Fluctuations found in this study may be due as [42] and [57] recorded for sea cucumbers, who reported that the mineral content can be linked to the high content of spicules have sea cucumbers in their body. It should be noted that the ash content in this work was obtained from muscle integument without any procedure to extract the spicules (decalcification), so it is believed that this might affected the percentages of ash obtained for Isostichopus sp.

In the other hand, marine invertebrates' humidity may vary between $65 \%$ and $95 \%$ with exceptions in some taxa [58]-[60]. During this study the moisture content was between $83.74 \%$ and $86.92 \%$, which values are within the ranges established previously by [21] for sea cucumber, and within those reported by [23] (81.24\% to 85.24\%), for three Holothuria species (H. tubulosa, H. polii and H. mammata) and [42], (84, 89\% and 91.30\%) in Stichopus japonicus. Humidity values in this study are above those reported by [54] (67.82\% and 69.45\%), in two species of sea cucumber Persian Gulf: H. arenicola and H. parva. These were recorded below that reported by [21] and [38], (88.8\% and 90.1\%), in Parastichopus californicus and those exposed by [41] in Cucumaria frondosa $(87.4 \%$ and $90.1 \%)$. Moisture percentages found in this study may be linked to the time of year, environmental factors, geographical variations or feeding behavior [21] [22] [40].

The results obtained in this study are consistent with those made in other species of sea cucumber, which allows us to set up that sea cucumbers, native of Santa Marta Caribbean Sea (Colombia), have a chemical composition with valuable nutritional properties, which could be used for consumption and pharmaceutical applications.

\section{Conclusion}

As a conclusion, the compositional analysis showed that Isostichopus sp. possesses valuable nutritional properties, including high percentage of protein (6.63\%) and low percentage of lipids (0.35\%). In addition, the highest values of protein and lipid content in muscle are related to the reproductive season which is probably linked to patterns of reproductive biology of the species. The nutritional composition of Isostichopus sp. fluctuates in line with environment changes, where in the dry season, values are low and in the rainy season these are higher. Native sea cucumber Isostichopus sp might be a potential candidate to be commercialized in worldwide markets with the highest consumption of bêche de mer or trepang. Isostichopus sp. could be used for human consumption because of its high nutritional value.

\section{Acknowledgements}

This work was supported by Colciencias Grant (No 1117-521-28356) and Vicerrectoría de Investigación (Universidad del Magdalena), Santa Marta, Colombia. Authors would like to thank sea cucumbers fisherman Jorge Polo who helped collecting holothurians and to the Group of Research and Technology Development in Aquaculture.

\section{References}

[1] AOAC (1990) Association of Official Analytical Chemists, Official Methods of Analysis. 15th Edition, AOAC International, Arlington.

[2] Graeve, M., Albers, C. and Kattner, G. (2005) Assimilation and Biosynthesis of Lipids in Arctic Calanus Species Based on Feeding Experiments with a 13C Labelled Diatom. Journal of Experimental Marine Biology and Ecology, 317, 109-125. http://dx.doi.org/10.1016/j.jembe.2004.11.016

[3] Nyssen, F., Brey, T., Dauby, P. and Graeve, M. (2005) Trophic Position of Antarctic Amphipods-Enhanced Analysis by a 2-Dimensional Biomarker Assay. Marine Ecology Progress Series, 300, 135-145. http://dx.doi.org/10.3354/meps300135

[4] Barbarino, E. and Lourenço, S.O. (2009) Comparison of CHN Analysis and Hach Acid Digestion to Quantify Total Nitrogen in Marine Organisms. Limnology and Oceanography: Methods, 7, 751-760. http://dx.doi.org/10.4319/lom.2009.7.751

[5] Diniz, G.S., Barbarino, E. and Lourenço, S.O. (2012) On the Chemical Profile of Marine Organisms from Coastal Subtropical Environments: Gross Composition and Nitrogen-to-Protein Conversion Factors. Oceanography, 297-320.

[6] Zaboukas, N., Miliou, H., Megalofonou, P. and Moraitou-Apostolopoulou, M. (2006) Biochemical Composition of the Atlantic Bonito Sarda sarda from the Aegean Sea (Eastern Mediterranean Sea) in Different Stages of Sexual Maturity. 
Journal of Fish Biology, 69, 347-362. http://dx.doi.org/10.1111/j.1095-8649.2006.01090.x

[7] Dubischar, C.D., Pakhomov, E.A., von Harbou, L., Hunt, B.P. V. and Bathmann, U.V. (2012) Salps in the Lazarev Sea, Southern Ocean: II. Biochemical Composition and Potential Prey Value. Marine Biology, 159, 15-24. http://dx.doi.org/10.1007/s00227-011-1785-5

[8] Zaia, D.M., Thaïs, C. and Zaia, B.V. (1998) Determinação de proteínas totais via espectrofometria: Vantagens e desvantagens dos métodos existentes. Química Nova, 21, 787-793. http://dx.doi.org/10.1590/s0100-40421998000600020

[9] Subramaniam, S., Fahy, E., Gupta, S., Sud, M., Byrnes, R.W., Cotter, D., Dinasarapu, A.R. and Maurya, M.R. (2011) Bioinformatics and Systems Biology of the Lipidome. Chemical Reviews, 111, 6452-6490. http://dx.doi.org/10.1021/cr200295k

[10] Brey, T., Müller-Wiegmann, C., Zittier, Z.M.C. and Hagen, W. (2010) Body Composition in Aquatic Organisms-A Global Data Bank of Relationships between Mass, Elemental Composition and Energy Content. Journal of Sea Research, 64, 334-340. http://dx.doi.org/10.1016/j.seares.2010.05.002

[11] Karakoltsidis, P.A., Zotos, A. and Constantinides, S.M. (1995) Composition of the Commercially Important Mediterranean Finfish, Crustaceans, and Molluscs. Journal of Food Composition and Analysis, 8, 258-273. http://dx.doi.org/10.1006/jfca.1995.1019

[12] Orban, E., Di Lena, G., Nevigato, T., Casini, I., Marzetti, A. and Caproni, R. (2002) Seasonal Changes in Meat Content, Condition Index and Chemical Composition of Mussels (Mytilus galloprovincialis) Cultured in Two Different Italian Sites. Food Chemistry, 77, 57-65. http://dx.doi.org/10.1016/S0308-8146(01)00322-3

[13] Sriket, P., Benjakul, S., Visessanguan, W. and Kijroongrojana, K. (2007) Comparative Studies on Chemical Composition and Thermal Properties of Black Tiger Shrimp (Penaeus monodon) and White Shrimp (Penaeus vannamei) Meats. Food Chemistry, 103, 1199-1207. http://dx.doi.org/10.1016/S0308-8146(01)00322-3

[14] Nurnadia, A.A., Azrina, A. and Amin, I. (2011) Proximate Composition and Energetic Value of Selected Marine Fish and Shellfish from the West Coast of Peninsular Malaysia. International Food Research Journal, 18, 137-148.

[15] Sánchez-Camargo, A.P., Almeida Meireles, M.Â., Lopes, B.L.F. and Cabral, F.A. (2011) Proximate Composition and Extraction of Carotenoids and Lipids from Brazilian Redspotted Shrimp Waste (Farfantepenaeus paulensis). Journal of Food Engineering, 102, 87-93. http://dx.doi.org/10.1016/j.jfoodeng.2010.08.008

[16] Diniz, G.S., Barbarino, E., Oiano Neto, J., Pacheco, S. and Lourenço, S.O. (2014) Proximate Composition of Marine Invertebrates from Tropical Coastal Waters, with Emphasis on the Relationship between Nitrogen and Protein Contents. Latin American Journal of Aquatic Research, 42, 332-352. http://dx.doi.org/10.3856/vol42-issue2-fulltext-5

[17] Stonik, V.A. and Elyakov, G.B. (1988) Secondary Metabolites from Echinoderms as Chemotaxonomic Markers. In: Scheuer, P., Ed., Bioorganic Marine Chemistry, Vol. 2, Springer, Berlin, 43-86. http://dx.doi.org/10.1007/978-3-642-48346-2 2

[18] Habermehl, G.G. and Krebs, H.C. (1990) Toxins of Echinoderms. In: Atta-ur-Rahman, Ed., Studies in Natural Products Chemistry, Vol. 7, Elsevier, Amsterdam, 265-316.

[19] Lawrence, J., Afifi, R., Ahmed, M., Khalifa, S. and Paget, T. (2010) Bioactivity as an Options Value of Sea Cucumbers in the Egyptian Red Sea: Contributed Paper. Conservation Biology, 24, 217-225.

http://dx.doi.org/10.1111/j.1523-1739.2009.01294.x

[20] Mottet, M.G. (1976) The Fishery Biology and Market Preparation of Sea Cucumbers. Washington Department of Fisheries Technical Report, No. 22.

[21] Chang-Lee, M.V., Price, R.J. and Lampila, L.E. (1989) Effect of Processing on Proximate Composition and Mineral Content of Sea Cucumbers (Parastichopus spp.). Journal of Food Science, 54, 567-568. http://dx.doi.org/10.1111/j.1365-2621.1989.tb04653.x

[22] Ginger, M.L., Billett, D.S.M., Mackenzie, K.L., Kiriakoulakis, K., Neto, R.R., Boardman, D.K., Santos, V.L.C.S., Horsfall, I.M. and Wolff, G. (2001) Organic Matter Assimilation and Selective Feeding by Holothurians in the Deep Sea: Some Observations and Comments. Progress in Oceanography, 50, 407-421. http://dx.doi.org/10.1016/S0079-6611(01)00063-5

[23] Aydin, M., Sevgili, H., Tufan, B., Emre, Y. and Köse, S. (2011) Proximate Composition and Fatty Acid Profile of Three Different Fresh and Dried Commercial Sea Cucumbers from Turkey. International Journal of Food Science \& Technology, 46, 500-508. http://dx.doi.org/10.1111/j.1365-2621.2010.02512.x

[24] Chen, J. (2003) Overview of Sea Cucumber Farming and Sea Ranching Practices in China. SPC Beche-de-mer Information Bulletin, 18, 18-23.

[25] Fredalina, B.D., Ridzwan, B.H., Abidin, Z., Kaswandi, M., Zaiton, H., Zali, I., Kittakoop, P. and Jais, M.M. (1999) Fatty Acid Compositions in Local Sea Cucumber, Stichopus chloronotus, for Wound Healing. General Pharmacology, 33, 337-340. http://dx.doi.org/10.1016/S0306-3623(98)00253-5 
[26] González, D., Navas, G. and Solano, O. (2002) Equinodermos colectados por la expedición CIOH-INVEMARSMITHSONIAN entre Cartagena y el Golfo de Urabá (29-380 m), Caribe colombiano. Boletín de Investigaciones Marinas y Costeras, 31, 85-132. (In Spanish)

[27] Borrero-Pérez, G., Benavides-Serrato, M., Solano, O. and Navas, G. (2004) Holothuroideos (Echinodermata: Holothuroidea) recolectados en el talud continental superior del Caribe Colombiano. Universidad de Oriente. Boletín del Instituto Oceanográfico de Venezuela, 42, 68-85.

[28] Rodríguez, A., Vergara, W. and Agudelo, V. (2013) First Insight into Colombian Caribbean Sea Cucumbers and Sea Cucumber Fishery. SPC Beche-de-mer Information Bulletin, 33, 9-13.

[29] Agudelo, V. and Rodríguez, A. (2013) Pepino de mar: Una alternativa para la diversificación de la maricultura en Colombia. Infopesca Internacional, 54, 22-27. (In Spanish)

[30] Audelo, V. and Rodríguez, A. (2015) Advances on Spontaneous Captive Breeding and Culture Conditions of Caribbean Sea Cucumber Stichopus sp. SPC Beche-de-mer Information Bulletin, 35, 50-57.

[31] Vergara, W. and Rodríguez, A. (2015) Histology of the Digestive Tract of Three Species of Sea Cucumber Isostichopus badionotus, Isostichopus sp. and Stichopus hermanni (Aspidochirotida: Stichopodidae). Revista de Biolog a Tropical, 63, 1021-1033. http://dx.doi.org/10.15517/rbt.v63i4.16887

[32] Andrade, C. and Barton, E. (2000) Eddy Development and Motion in the Caribbean Sea. Journal of Geophysical Research, 105, 26191-26201. http://dx.doi.org/10.1029/2000JC000300

[33] Poveda, G. (2004) Hydroclimatology of Colombia: A Synthesis from the Inter-Decadal Scale to Scale Diurnal Scale. Revista de la Academia Colombiana de Ciencias, 28, 201-222. (In Spanish)

[34] Poveda, G., Waylen, P.R. and Pulwarty, R.S. (2006) Annual and Inter-Annual Variability of the Present Climate in Northern South America and Southern Mesoamerica. Palaeogeography, Palaeoclimatology, Palaeoecology, $234,3-27$. http://dx.doi.org/10.1016/j.palaeo.2005.10.031

[35] Hoyosa, N., Escobara, J., Restrepo, J.C., Arango, A.M. and Ortiz, J.C. (2013) Impact of the 2010-2011 La Niña phenomenon in Colombia, South America: The Human Toll of an Extreme Weather Event. Applied Geography, 39, 16-25. http://dx.doi.org/10.1016/j.apgeog.2012.11.018

[36] Centro de Investigaciones Oceanográficas e Hidrográficas del Caribe (CIOH) Circulación general de la atmósfera en Colombia. http://www.cioh.org.co/ http://www.cioh.org.co/meteorologia/Climatologia/ResumenSantaMarta4.php

[37] Huss, H.H., Ababouch, L. and Gram, L. (2003) Assessment and Management of Seafood Safety and Quality. FAO Fisheries Technical Paper 444, 1-230.

[38] Liu, G., Yang, H. and Liu, S. (2010) Effects of Rearing Temperature and Density on Growth, Survival and Development of Sea Cucumber Larvae, Apostichopus japonicus (Selenka). Chinese Journal of Oceanology and Limnology, 28, 842-848. http://dx.doi.org/10.1007/s00343-010-9092-4

[39] Çakli, Ş., Cadun, A., Kişla, D. and Dinçer, T. (2004) Determination of Quality Characteristics of Holothuria tubulosa, (Gmelin, 1788) in Turkish Sea (Aegean Region) Depending on Sun Drying Process Step Used in Turkey. Journal of Aquatic Food Product Technology, 13, 69-78. http://dx.doi.org/10.1300/J030v13n03_07

[40] Özer, N.P., Mol, S. and Varlık, C. (2005) Effect of the Handling Procedures on the Chemical Composition of Sea Cucumber. Turkish Journal of Fisheries and Aquatic Sicences, 74, 71-74.

[41] Zhong, Y., Khan, M.A. and Shahidi, F. (2007) Compositional Characteristics and Antioxidant Properties of Fresh and Processed Sea Cucumber (Cucumaria frondosa). Journal of Agricultural and Food Chemistry, 55, 1188-1192. http://dx.doi.org/10.1021/jf063085h

[42] Tanikawa, E., Akiba, M. and Yoshitani, S. (1955) Studies on the Nutritive Value of the Meat of Sea Cucumber (Stichopus japonicus Selenka). II. Seasonal Changes of Chemical Components of the Meat of Stichopus japonicus. Bulletin of the Faculty of Fisheries, Hokkaido University, 5, 341-345.

[43] Lee, M.-H., Kim, Y.-K., Moon, H., Kim, K.-D., Kim, G.G., Cho, H.A., Yoon, N., Sim, K., Park, H.-Y., Lee, D.-S., Lim, C.W., Yoon, H.D. and Han, S.K. (2012) Comparison on Proximate Composition and Nutritional Profile of Red and Black Sea Cucumbers (Apostichopus japonicus) from Ulleungdo (Island) and Dokdo (Island), Korea. Food Science and Biotechnology, 21, 1285-1291. http://dx.doi.org/10.1007/s10068-012-0169-z

[44] Li, D.T., Chang, Y.Q., Wu, Z.H., Chen, W., Wang, J.Y. and Cheng, G.D. (2009) Analysis of Nutritive Composition of Body Wall in Wild Sea Cucumber Apstichopus japonicus Selenka at Zhangzi Island in Spring and Autumn. Fisheries Science, 28, 365-369.

[45] Johnson, R.B. (2009) Lipid Deposition in Oocytes of Teleost Fish during Secondary Oocyte Growth. Reviews in Fisheries Science, 17, 78-89. http://dx.doi.org/10.1080/10641260802590004

[46] Hudson, I.R., Wigham, B.D., Billett, D.S.M. and Tyler, P. (2003) Seasonality and Selectivity in the Feeding Ecology 
and Reproductive Biology of Deep-Sea Bathyal Holothurians. Progress in Oceanography, 59, 381-407. http://dx.doi.org/10.1016/j.pocean.2003.11.002

[47] Hudson, I.R., Pond, D.W., Billett, D.S.M., Tyler, P., Lampitt, R.S. and Wolff, G. (2004) Temporal Variations in Fatty Acid Composition of Deep-Sea Holothurians: Evidence of Bentho-Pelagic Coupling. Marine Ecology Progress Series, 281, 109-120. http://dx.doi.org/10.3354/meps281109

[48] Ibrahim, M.Y., Sheikheldin, M.E., Yousif, B., Gideiri, A. and Ali, S.M. (2015) The Proximate Composition and the Nutritional Value of Some Sea Cucumber Species Inhabiting the Sudanese Red Sea. Food Science and Quality Management, 41, 11-16.

[49] Yang, H., Hamel, J-F. and Mercier, A. (2015) The Sea Cucumber Apostichopus japonicus: History, Biology and Aquaculture. Academic Press, Cambridge, 478 p.

[50] Fawzya, Y.N., Januar, H.I., Susilowati, R. and Chasanah, E. (2015) Chemical Composition and Fatty Acid Profile of Some Indonesian Sea Cucumbers. Squalen Bulletin of Marine \& Fisheries Postharvest \& Biotechnology, 10, 27-34. http://dx.doi.org/10.15578/squalen.v10i1.118

[51] Özer, N.P., Sühendan, Mol, S. and Varlýk, C. (2004) Effect of the Handling Procedures on the Chemical Composition of Sea Cucumber. Turkish Journal of Fisheries and Aquatic Sicences, 4, 71-74.

[52] Neto, R.R., Wolff, G.A., Billett, D.S.M., Mackenzie, K.L. and Thompson, A. (2006) The Influence of Changing Food Supply on the Lipid Biochemistry of Deep-Sea Holothurians. Deep-Sea Research I, 53, 516-527. http://dx.doi.org/10.15578/squalen.v10i1.118

[53] Omran, N.S. (2013) Nutritional Value of Some Egyptian Sea Cucumbers. African Journal of Biotechnology, 12, 54-66.

[54] Salarzadeh, A., Afkhami, M., Bastami, K.D., Ehsanpour, M., Khzaali, A. and Mokhleci, A. (2012) Proximate Composition of Two Sea Cucumber Species Holothuria pavra and Holothuria arenicola in Persian Gulf. Annals of Biological Research, 3, 1305-1311.

[55] Ridzwan, B.H., Hanita, M.H., Nurzafirah, M., Norshuhadaa, M.P.S. and Hanis, Z.F. (2014) Free Fatty Acids Composition in Lipid Extracts of Several Sea Cucumbers Species from Malaysia. International Journal of Bioscience, Biochemistry and Bioinformatics, 4, 204-207. http://dx.doi.org/10.7763/IJBBB.2014.V4.340

[56] Bordbar, S., Anwar, F. and Saari, N. (2011) High-Value Components and Bioactives from Sea Cucumbers for Functional Foods—A Review. Marine Drugs, 9, 1761-1805. http://dx.doi.org/10.3390/md9101761

[57] Smiley, S. (1994) Holothuroidea. Microscopic Anatomy of Invertebrates, 14, 401-471.

[58] Kechaou, E.S., Dumay, J., Donnay-Moreno, C., Jaouen, P., Gouygou, J.P., Bergé, J.P. and Amar, R.B. (2009) Enzymatic Hydrolysis of Cuttlefish (Sepia officinalis) and Sardine (Sardina pilchardus) Viscera Using Commercial Proteases: Effects on Lipid Distribution and Amino Acid Composition. Journal of Bioscience and Bioengineering, 107, 158-164. http://dx.doi.org/10.1016/j.jbiosc.2008.10.018

[59] Sykes, A.V., Oliveira, A.R., Domingues, P.M., Cardoso, C.M., Andrade, J.P. and Nunes, M.L. (2009) Assessment of European Cuttlefish (Sepia officinalis, L.) Nutritional Value and Freshness under Ice Storage Using a Developed Quality Index Method (QIM) and Biochemical Methods. LWT-Food Science and Technology, 42, 424-432. http://dx.doi.org/10.1016/j.lwt.2008.05.010

[60] Biol, J.M., Karthikeyan, M.M., Ananthan, G. and Balasubramanian, T. (2011) Biochemical Components of a Solitary Ascidian Microcosmus exasperatus Heller, 1878 (Ascidiacea: Pyuridae). Journal of the Marine Biological Association of India, 53, 139-141. 